\title{
Palm Secondary Products as a Source of Organic Material for Compost Production: Applied Examples from Egypt
}

\author{
Mohamed Mahmoud Mohamed Ahmed \\ Soil, Water and Environment Research Institute, Agriculture Research Center, Giza, Egypt \\ m311332@hotmail.com
}

Keywords: pruning products, composting, Date Palm Residues, Doum Palm residues

\begin{abstract}
The increasing amounts of fruit pruning wastes in local societies of Egypt cause environmental problems closely related to human health. Its utilization as renewable materials has received a great attention in our present days and encouraged the use of it as an organic fertilizer. Composting these wastes not only reduces their weight and volume but also produces high-value-added products (compost). Manure is the most common organic and natural fertilizer form in our Egyptian rural Village. Due to the high cost of chemical fertilizers and the increase of organic fertilizers demand, it is necessary to use the local crop residues, "Palm Secondary Products" (PSP) as a basic (raw) material which contains 92.99\% organic matter. Compost manufacturing provides successfully produce an organic fertilizer from available waste in each region which serves as both fertilizers and soil conditioners. In this study, we present Egyptian examples of the recycling of date palm pruning products mixed with other organic wastes in small scale (Faris rural village, Kom-Ombo, Aswan Governorate and Mandisha village, Baheria oases, Giza Governorate) and in large scale (Al-Kharga, New Valley Governorate).
\end{abstract}

\section{Introduction}

The total world number of date palms is about 120 million trees, distributed in 30 countries and producing nearly 7.5 million tons of fruit per year [1]. Arab countries account for $70 \%$ of the world's date palms number and are responsible for $67 \%$ of the global production of date palm [2]. The total number of palm tree planted in Egypt is 16 million including 12 million fruiting tree [3]. Mohamed [4] reported that the significant annual increase of fruit dates was about 298.9 thousand palm trees, equivalent to $2.75 \%$ of the average number of fruitful dates during the period (1997 - 2012). Due to its adaptation to various stress condition, its plantation is nowadays spread out all over Egypt including the new reclaimed land in the desert and in saline-affected areas. The utilization of by-products of date palm as raw material source for industrial activities gave a promising issues. Some studies have reported that Egypt alone generates more than 300,000 tons of date palm biomass each year [5].

Although date palm residues (DPR) consist of hardly decomposed elements (Cellulose, hemicelluloses, lignin and other compounds) they could be composted with microbiological process instead of burning in farms and causing serious threat to environment [6]. Many researchers reported about compost production from date palm by products [7, 8, 9, 10, and 11].

It should be noted that Egyptian agriculture is mainly dependent on chemical fertilizers (nitrogen, phosphates and potassium) and organic fertilizers. So, recycling palm residues could reduce chemical fertilizers as well as the impact of drought and desertification and pesticides. Moreover, social, economic and environmental benefits could be obtained from the Recycling palm residues including increasing agricultures production in quantity and quality. 


\section{Materials and Methods}

There are 3 experiments of DPR composting; two of them were conducted in small scale in compost units in different Egyptian village (Faris village Kom-Ombo - Aswan and Mandisha village, Baheria Oasis - Giza Governorate) and the other experiment was made in large scale in sustainable integrated system in (Al-Kharga, New Valley Governorate).

Experiment 1. Faris village is an Egyptian rural village, which located in the west side of the Nile in Kom Ombo, Aswan Governorate. It produces annually about 5000 tons of renewable biomass from fruit trees as date palm (Phoenix daetylifera), Mango (Anacardiaceae) and doum palm (Hyphaene thebicia). Palm secondary products (PSP) represent about $80 \%$ of this total [11]. The first stage was conducted in site which residues were collected and transported to this site which called (fixed shredding system). Meanwhile, in pilot stage shredding and composting process was made where the residues accumulated (mobile shredding system). The amount of compost produced at pilot stage is equivalent to $70 \%$ of the total waste of palm trees. This is in addition to $20 \%$ Mango residues and 10\% Doum palm residues. Filter mud cake by product produced from sugar can industry in this region was used as organic activator in composting process. About 45 tons and 33 tons of compost were produced in the first and pilot stage respectively. The produced compost was distributed on the local farmers to use in the cultivation of onion crop.

Experiment 2. Baheria Oasis is a depression and lies in the Western Desert of Egypt. Located in Giza Governorate, the main economic sectors are agriculture. The number of palm trees in the oases is estimated at 1.3 million palms; the wealth of palm oases is about $10 \%$ of Egypt's total palm wealth (according to estimates that the number of palm trees in Egypt is approximately 13 million palm trees) El-Mously [12]. Large quantities of PSP are available; currently estimated at 69.5 thousand tons / year (dry weight); these quantities are not only abundant but also renewable diversity and pricing, and the possibility of using them as inputs to the manufacturing of many products (as confirmed in this study). A pilot experiment of compost production was conducted in the village of Mandisha. The main additive material in composting process was poultry manure wastes as a common by product of Poultry Industry used as compost activator material. About 3 ton compost was produced from 8 ton DPR $+8 \mathrm{~m}^{3}$ poultry manure.

Experiment 3. The New Valley Governorate is considered the largest governorate in Egypt with a total area represents about 44\% of Egypt's area. Date palms (more than 1.5 million palm trees) represent the economic axis of the governorate. A study of the development of the number of fruitful dates in the New Valley Governorate reveal that these numbers has increased significantly by $1.28 \%$ during the period from 1997 to 2012 [4]. The date palm pruning produces large amounts of PSP, leading to serious environmental problems. The governorate has approximately 92503 tons per year according to the report of the Directorate of Agriculture in the Governorate of [13]. Experimental pilot attempts produce about 170 ton compost. The main additive materials in composting process was Farmyard manure (FYM) as common by product of cattle Husbandry as organic activator.

\section{Analysis of Fiber Derivatives}

Fiber Derivatives of date palm, Mango and Doum palm residues were determined according to TAPPI standard method. The samples were first placed into soxhlet extraction for 6 hours according to method T $264 \mathrm{~cm}-07$ to remove plant extractives. The determination of cellulose, hemicellulose and lignin content were assessed by using the following respective standard method: Kurscher-Hoffner approach [14], chlorite [15], T 222 om-06 and T 211 om-07. As recommended by various pertinent standards, all experiments were conducted in triplicates. 


\section{Characterization of compost}

Compost resulting from 3 experiments was analyzed. Compost samples were dried at $70{ }^{\circ} \mathrm{C}$ to constant weight ground. Values of $\mathrm{pH}$ and EC were determined as described by Jackson [16]. The organic matter (OM) content of compost was analyzed by weight loss on ignition at $43{ }^{\circ} \mathrm{C}$ for $24 \mathrm{~h}$ and total organic carbon (TOC) was calculated from (OM) to the following equations [17]:

$$
\mathrm{OM}=\left[\left(\mathrm{W}_{105}-\mathrm{W}_{430}\right) / \mathrm{W}_{105}\right] \times 100
$$

Where $\mathrm{W} 105=$ oven dry weight of mass at $105^{\circ} \mathrm{C}$; W430 = furnace dry weight of mass at $430^{\circ} \mathrm{C}$

$$
\mathrm{TOC}=0.51 \times \mathrm{OM}+0.48
$$

Compost samples were digested using a mixture of $\mathrm{H}_{2} \mathrm{O}_{2}$ and $\mathrm{H}_{2} \mathrm{SO}$. Total nitrogen was determined by using the micro-kjeldahl procedure [16]. Total phosphorus and potassium were determined by Page et al. [18]. Moisture content throughout this study was measured by drying at $105^{\circ} \mathrm{C}$ for approximately $24 \mathrm{~h}$ or at constant weight. Bulk density $\left(\mathrm{B}_{\mathrm{d}}\right)$ was measured by obtaining the dry weight of a known volume of the sample. Bulk density was calculated by the following formula [19]:

$$
\mathrm{B}_{\mathrm{d}}=\mathrm{M}_{\mathrm{s}} / \mathrm{V}_{\mathrm{t}}
$$

Where $\mathrm{M}_{\mathrm{s}}$ is mass of oven dry compost (g), and $\mathrm{V}_{\mathrm{t}}$ is total volume of compost $\left(\mathrm{cm}^{3}\right)$.

\section{Results and Discussion}

DPR materials are rich in some nutrients and can be returned to the field as compost. The economic losses and the financial waste resulting from the non-use or use of the by-products of palm trees in the oases; most of which are disposed of either by open burning in the fields, which contributes to the increase of environmental pollution. Storage in the fields prevents land to cultivation, leading to many environmental problems caused by many insects and rodents, which helps to reproduce and the transmission of diseases and epidemics ... etc.

Table 1: Quantity of PSP in dry weight and its nutrient content in all sites under the study.

\begin{tabular}{|l|c|c|c|c|}
\hline \multicolumn{1}{|c|}{ Oasis } & \multirow{2}{*}{$\begin{array}{c}\text { Residues } \\
\text { quantity } \\
\text { Thousand (ton) }\end{array}$} & \multicolumn{3}{|c|}{$\begin{array}{c}\text { Nutrients content } \\
\text { \%)( }\end{array}$} \\
\cline { 5 - 5 } & & $\begin{array}{c}\text { Nitrogen } \\
\text { N }\end{array}$ & $\begin{array}{c}\text { Phosphorous } \\
\text { P }\end{array}$ & $\begin{array}{c}\text { Potassium } \\
\text { K }\end{array}$ \\
\hline Faris* & 5.000 & 0.84 & 0.22 & 0.80 \\
\hline Baheria Oases** & 69.532 & & 0.22 & \\
\hline Al-Kharga*** & 29.075 & & & \\
\cline { 1 - 2 } & & & &
\end{tabular}

* El-Mously [20]; ** El-Mously [12]; ***Official Records at the Directorate of Agriculture, Markaz El Waadi El Gadid Governorate [13].

Based on nutrient content in palm residues (Table 1), these residues are rich in nitrogen and potassium. Consequently, each ton from PSP content has approximately about $8.40 \mathrm{~kg}$ of Nitrogen and $8.0 \mathrm{~kg}$ of potassium. The value of nutrients removed is estimated as the cost of 
fertilizers that will be needed to replace these nutrients. In view of the available large quantities of PSP in the oases under the study, these quantities are not only abundant but also renewable Diversity and pricing, and the possibility of using it as inputs to the manufacturing of many products (as confirmed in this study).

Experiment 1. Composting of PSP in small scale (Faris rual village Kom-Ombo - Aswan):

Data in table 2 show the percentage content of Fiber Derivatives of date palm, Mango and Doum palm residues is which show clearly the Plant-derived cellulose materials which play a critical role as organic wastes in composting to produce a beneficial amendment for topsoil. Hubbe et al. [21] reported that Cellulose has been described as a main source of energy to drive the biological transformations and the consequent temperature rise and chemical changes that are associated with composting. Lignin can be viewed as a main starting material for the formation of humus.

Table 2: Analysis of Fiber Derivatives of palm, Mango and Doum residues

\begin{tabular}{|l|c|c|c|}
\hline Residues type & $\begin{array}{c}\text { Lignin } \\
\mathbf{( \% )}\end{array}$ & $\begin{array}{c}\text { Hemicellulose } \\
\mathbf{( \% )}\end{array}$ & $\begin{array}{c}\text { Cellulose } \\
\mathbf{( \% )}\end{array}$ \\
\hline $\begin{array}{l}\text { Date palm } \\
\text { residues }\end{array}$ & 35,74 & 4.75 & 12.27 \\
\hline Mango residues & 40.50 & 0.57 & 14.57 \\
\hline $\begin{array}{l}\text { Doum palm } \\
\text { residues }\end{array}$ & 35.19 & 13.82 & 10.81 \\
\hline
\end{tabular}

The analysis of produced compost with its highly organic matter (40.69\%), which improves soil fertility, was shown in table 3 . Compost acts as sponge to help retain water in the soil that would otherwise drain down below the reach of plant roots, protecting the plant against drought. Results of the pilot fields on onion cultivation showed that the use of Faris compost increased the average onion yield by $10.22 \%$ compared to the use of they own organic manure (fig. 1). This increase represents the direct effect of compost application. Indirect impacts were known that organic fertilization helps keep the soil moist for a long time which reduces irrigation periods and thus reduces irrigation costs of energy and labor and helps to rationalize the consumption of irrigation water.

Table 3: Physiochemical analysis of Faris compost

\begin{tabular}{|l|c|}
\hline \multicolumn{1}{|c|}{ Parameter } & Faris compost \\
\hline $\mathrm{pH}(1: 10)$ & 7.75 \\
EC $\left(\mathrm{dSm}^{-1}\right)(1: 10)$ & 3.87 \\
Organic C (\%) & 23.66 \\
Organic matter (\%) & 40.69 \\
Nitrogen (\%) & 0.92 \\
C/N ratio & $14.22: 1$ \\
Phosphorous (\%) & 0.48 \\
Potassium (\%) & 0.67 \\
Bulk density (g cm & $-3)$ \\
Moisture (\%) & 715 \\
\hline
\end{tabular}




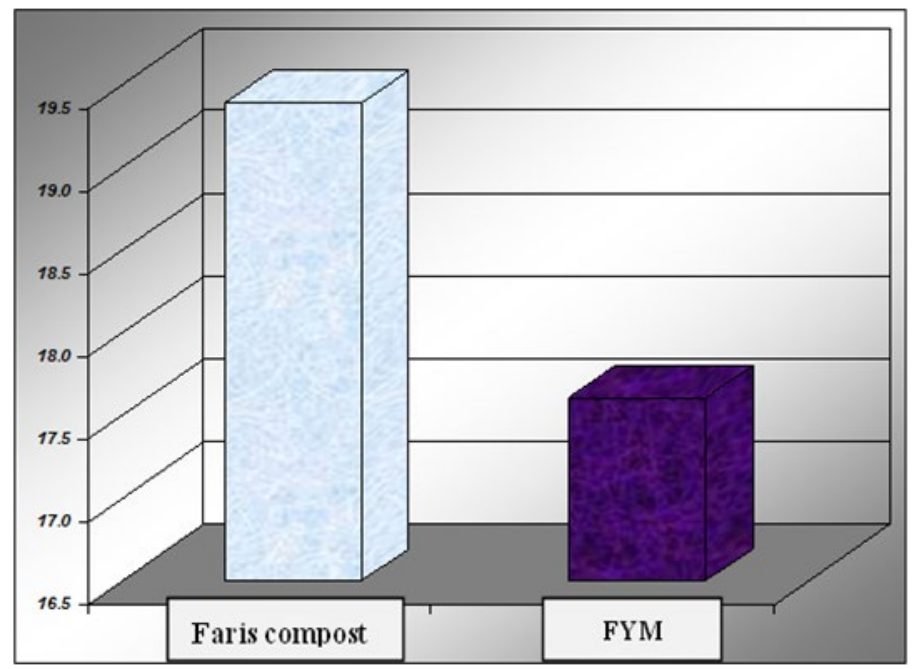

Fig. 1: A graph showing the productivity of onion crop by using faris compost (19.4ton/fed) compared to the use of Farmyard manure (17.6 ton/fed).

Experiment 2. Composting of PSP in small scale (Mandisha village, Baheria Oases - Giza Governorate:

A part of the experiment demonstrates a study on compost production in large scale in the Baheria oases reveal that there are a great possibilities to provide a compost facility with 100 ton PSP each day with a total of 30,000 ton of PSP annually to produce 60-70 ton compost daily. So, it's suggested to establishing compost facility utilized half of the PSP in Baheria oasis and the remained quantity could be used in another industry activity for Medium density fiberboard (MDF) production. Some physical and chemical analyses of the produced compost were showed in table 4.

Table 4: Physiochemical analysis of Baheria oases compost.

\begin{tabular}{|l|c|}
\hline Parameter & Baheria oasis compost \\
\hline $\mathrm{pH}(1: 10)$ & 7.84 \\
$\mathrm{EC}\left(\mathrm{dS} \mathrm{m} \mathrm{m}^{-1}\right)(1: 10)$ & 4.61 \\
Organic C (\%) & 26.54 \\
Organic matter (\%) & 45.66 \\
Nitrogen (\%) & 1.12 \\
C/N ratio & $21.75: 1$ \\
Phosphorous (\%) & 0.61 \\
Potassium (\%) & 0,91 \\
Bulk density (g cm & -3 ) \\
Moisture (\%) & 678 \\
\hline
\end{tabular}

Experiment 3. Composting of PSP in large scale (Al-Kharga) New Valley - New Valley Governorate:

Experimental pilot attempts produce about 170 ton compost with high quality value sold by 36524 LE [22]. The main additive materials in composting process was Farmyard manure (FYM) as common by product of cattle Husbandry as organic activator. Analysis of palm compost in the Experimental pilot attempts of the New valley are demonstrated in table 5. 
Table 5: Physiochemical analysis of New valley compost.

\begin{tabular}{|l|c|}
\hline \multicolumn{1}{|c|}{ Parameter } & New valley compost \\
\hline $\mathrm{pH}(1: 10)$ & 8.38 \\
$\mathrm{EC}\left(\mathrm{dS} \mathrm{m} \mathrm{m}^{-1}\right)(1: 10)$ & 3.45 \\
Organic C (\%) & 22.97 \\
Organic matter (\%) & 46.38 \\
Nitrogen (\%) & 0.95 \\
C/N ratio & $17.17: 1$ \\
Phosphorous (\%) & 0.74 \\
Potassium (\%) & 0.94 \\
Bulk density (g cm & -3 \\
Moisture $(\%)$ & 600 \\
\hline
\end{tabular}

Adoption of some industry activities targeted to provide PSP raw materials in the Egyptian oases (such as compost industries) achieves two goals:

First: Economic loss and financial waste resulting from the non-use or utilization of the byproducts of palm trees in the oases:

The chemical fertilizer that equivalent to nutrient content in the PSP and its values are estimated according to nutrient analysis and demonstrated in table 6. Data clearly expressed that the total losses were 1398, 19463 and 8130 LE due to burning PSP in Faris village, Baheria oasis and Al-Kharga, respectively.

Table 6: Quantity of mineral fertilizer equivalent to nutrient content of PSP in dry weight and its value in each site under the study.

\begin{tabular}{|c|c|c|c|c|c|c|c|c|}
\hline \multirow[t]{3}{*}{ Oasis } & \multirow{3}{*}{$\begin{array}{c}\text { PSP } \\
\text { quantity } \\
\text { Thousand } \\
\text { (ton) }\end{array}$} & \multicolumn{6}{|c|}{ Fertilizers (kg) } & \multirow{3}{*}{$\begin{array}{c}\text { Total } \\
\text { Values } \\
\text { LE }\end{array}$} \\
\hline & & \multicolumn{2}{|c|}{ Urea } & \multicolumn{2}{|c|}{$\begin{array}{c}\text { Super } \\
\text { phosphate }\end{array}$} & \multicolumn{2}{|c|}{$\begin{array}{c}\text { Potassium } \\
\text { sulphate }\end{array}$} & \\
\hline & & $\begin{array}{c}\mathrm{Q} \\
\mathrm{Kg}\end{array}$ & $\begin{array}{c}\mathrm{V} \\
\mathrm{LE}\end{array}$ & Q & $\mathrm{V}$ & $\mathrm{Q}$ & $\mathrm{V}$ & \\
\hline Faris* & 5.000 & 90 & 361 & 16 & 33 & 100 & 1004 & 1398 \\
\hline Baheria Oases** & 69.532 & 1256 & 5024 & 226 & 452 & 1397 & 13970 & 19463 \\
\hline Al-Kharga*** & 29.075 & 525 & 2101 & 95 & 189 & 584 & 5840 & 8130 \\
\hline
\end{tabular}

* El-Mously [19]; ** El-Mously [12]; ***Official Records at the Directorate of Agriculture, Markaz El Waadi El Gadid Governorate [13]; Q Kg = Quantity of fertilizer; V LE =Value Egypt Pound; Urea $=$ N X 0.46, Tri-calcium; phosphate $37.5 \%=$ P X 0.375; Potassium sulphate $48 \%=$ N X 0.48; Fertilizers price: Urea $=4000$ EL/ ton; Super Phosphate $=2000$ EL / ton; Potassium sulphate $=10000 \mathrm{EL} /$ ton .

Second: Environmental loss: Open burning in the fields contributes to the increase of environmental pollution and $\mathrm{CO}^{2}$ emissions:

Palm trees have a big potential in absorbing $\mathrm{CO}_{2}$ from the atmosphere. It was demonstrated that one million mature date palm trees can absorb 2.0 million tons of $\mathrm{CO}_{2}$. Based on photosynthesis calculations, It is common that burning one ton of carbon produces 3.66 tons of 
$\mathrm{CO}_{2}$ as per the following reaction: $\mathrm{C}+\mathrm{O}_{2}=\mathrm{CO}_{2}$ [23]. It's known that carbon constitutes $50 \%$ of the dry wood, so the carbon part represents half of the demonstrated PSP.

Data in Table 7 show the huge amount of $\mathrm{CO}_{2}$ that will produce annually from burning date palm residues in open field which contributes to regional and global climate change by producing $\mathrm{CO}_{2}$, methane, and cause loss of human life in our societies. Data in table 7 shows that $\mathrm{CO}_{2}$ emissions increased with increasing the burning residues, the emission of $\mathrm{CO}_{2}$ was differing from a small quantity (9150 ton) to a large quantity in the new valley (127243 ton). Data also shows that carbon quantity $=50 \%$ from dry wood materials (residues) and Burning 1 ton residues $=3.66$ ton $\mathrm{CO}_{2}$.

Composting the agricultural residual lowered emission and sequestrate carbon in soils. Luske [24] reported that composting facility in Egypt show that the composting scenario causes significant lower emissions than the baseline scenario (organic waste is not recycled and chemical fertilizer is used on the farm). It must be recommended that farmers in our land should receiving information about modern methods of agricultural waste management and cleaning fields for planting.

Table 7: The expected quantities of $\mathrm{CO}_{2}$ emission (thousand ton) in case of burning PSP in each site.

\begin{tabular}{|l|c|c|c|}
\hline \multicolumn{1}{|c|}{ Oasis } & $\begin{array}{c}\text { PSP Thousand } \\
\text { (ton) }\end{array}$ & $\begin{array}{c}\text { Carbon } \\
\text { quantity } \\
\text { Thousand } \\
\text { (ton) }\end{array}$ & $\begin{array}{c}\mathbf{C O}_{2} \text { emissions } \\
\text { Thousand } \\
\text { (ton) }\end{array}$ \\
\hline Faris* & 5.000 & 2.500 & 9.15 \\
\hline Baheria Oasis** & 69.532 & 34.766 & 127.243 \\
\hline Al-Kharga*** & 29.075 & 14.537 & 53.207 \\
\hline
\end{tabular}

* El-Mously [19]; ** El-Mously [12]; ***Official Records at the Directorate of Agriculture, Markaz El Waadi El Gadid Governorate [13].

\section{Conclusion}

According to the experience, it could be concluded that pruning products are considered as recyclable materials and useful resource. The successful composting of PSP on a small scale in rural communities of Egypt will depend on farmers' awareness of the importance of exploiting the various date palm residues in compost production which will encourage the farmer of each local community over time to participate in producing his own compost.

\section{Acknowledgement}

The author wishes to express his sincere gratitude and appreciation to Prof. Dr. H.I. El-Mosely and all members the Egyptian Society for Endogenous Development of Local Communities (EGYCOM).

\section{References}

[1] FAO, Food and Agriculture Organization statistical database (FAOSTAT), Retrieved from http://faostat3.fao.org/, 2013.

[2] L.I. El-Juhany, Surveying of Lignocellulosic Agricultural Residues in Some Major Cities of Saudi Arabia; Research Bulletin No. 1-Agricultural Research Center, College of Agriculture, 
King Saud University: Riyadh, Saudi Arabia, 2001. https://doi.org/10.18006/2017.5(spl-1safsaw).s136.s147

[3] FAOSTAT, Crop Production 2008, Statistics Division, Food and Agriculture Organization of the United Nations, 2009.

[4] M.M.A.H. Mohamed, An economic head to promote the production and marketing of dates in the New Valley Governorate: Ph.D Thesis, Assiut University - Faculty of Agriculture Agricultural Economics, 2014.

[5] E.S. Setyawan, Charcoal Briquette Production in the Middle East: Perspectives, BioEnergy Consult, Powering Clean Energy Future, https://www.bioenergyconsult.com/tag/date-palmbiomass/, 2018.

[6] S.Y. Wong, S.S. Lin, Composts as soil supplement enhances plant growth and fruit quality of straw berry. Plant Nutrition, 25 (2002) 2243-2259. https://doi.org/10.1081/pln-120014073

[7] M.M.M. Ahmed, Composting of date palm residues to produce high value organic fertilizer, Conference titled "The role of scientific research in the development of small industries and the environment in the New Valley", Al-Kharja. New Valley governorate, 2005.

[8] M.S.A. Safwat, Organic Farming of Date Palm and Recycling of Their Wastes, African Crop Science Conference Proceedings, 8 (2007) 2109-2111.

[9] O.A.M. Mahmoud, Composting of date palm wastes and its effect on soil productivity and some soil properties: M.Sc. Thesis, Botany Department, Fac. Of Agric, Assiut Univ., Egypt, 2010.

[10] M.W. Sadik, A.O. Al Ashhab, M.K. Zahran, F.M. Alsaqan, Composting mulch of date palm trees through microbial activator in Saudi Arabia, International Journal of Biochemistry and Biotechnology 1 (2012) 156-161.

[11] M.M.M. Ahmed, Recycling of pruning products of date palm, doum palm and mango as a source of organic fertilizer, The 2nd International conference for Date Palm (ICDP), Al-Qassim Uni. Saudi Arabia, 2016.

[12] H. El-Mously, The final report "The improvement of environmental conditions and palm care and the economic use of its secondary products In the Baheria Oases", 2016.

[13] Official Records at the Directorate of Agriculture, Markaz El Waadi El Gadid Governorate, 2013.

[14] N. Cordeiro, M.N. Belgacem, I.C. Torres, J.C.V.P. Moura, Chemical Composition and Pulping of Banana Pseudo-Stems. Industrial Crops and Products, 19 (2004) 147-154.

https://doi.org/10.1016/j.indcrop.2003.09.001

[15] J.S. Han, J.S. Rowell, Chemical Composition of Fibers, In R. M. Rowell, R. A. Young, J. K. Rowell, (Ed.), Paper and Composites from Agro-Based Resources. United States: CRC Press, 1997, pp. 83- 134. https://doi.org/10.1016/s0144-8617(99)00096-X

[16] M. L. Jackson, Soil Chemical Analysis, Prentice-Hall of India Private Limited, New Delhi, 1973, pp. 498. 
[17] A.F. Navarro, J. Cegarra, A. Roig, D. Garcia, Relationships between organic matter and carbon contents of organic waste, Bioresource Technology, 44 (1993) 203-207. https://doi.org/10.1016/0960-8524(93)90153-3

[18] A.L. Page, R.H. Miller, D.R. keeney, Methods of Soil Analysis П: Chemical and Microbiological Properties, American Society of Agronomy Inc. Bull., Madison, Wisconsin, USA, 1982.

[19] S.D. BAO, Soil Physical and Chemical Analysis, Chinese Agricultural Press: Beijing, 2000, pp. 67-127.

[20] H. El-Mously, The final report "Project of compost production of palm, mango and Doum residues". 2012.

[21] M. A. Hubbe, M. Nazhad, C. Sánchez, Composting of lignocellulosics. BioResources, 5 (2010) 2808-2854.

[22] Official Records at the Directorate of Agriculture, Markaz El Waadi El Gadid Governorate, 2011.

[23] A. O. M. S. Sharifa, H.M. Talebb, The Date Palm and its Role in Reducing Soil Salinity and Global Warming, Blessed Tree, 2011.

[24] B. Luske, Composting as an emission reduction methodology and carbon footprint calculations of products, Reduced GHG emissions due to compost production and compost use in Egypt, Comparing two scenarios, Louis Bolk Instituut, 2010, pp. 30. 